"This is the peer reviewed version of the following article: Are firms that contribute to sustainable development better financially?, which has been published in final form at https://onlinelibrary.wiley.com/doi/abs/10.1002/csr.1347. This article may be used for noncommercial purposes in accordance with Wiley Terms and Conditions for Use of Self-Archived Versions." 
"This is the peer reviewed version of the following article: Are firms that contribute to sustainable development better financially?, which has been published in final form at https://onlinelibrary.wiley.com/doi/abs/10.1002/csr.1347. This article may be used for noncommercial purposes in accordance with Wiley Terms and Conditions for Use of Self-Archived Versions."

\title{
Are firms that contribute to sustainable development better financially?
}

\author{
Carmen-Pilar Martí-Ballester* \\ Business Economics Department \\ Center for Studies and Research in Humanities \\ Universitat Autònoma de Barcelona
}

\author{
M.Rosa Rovira-Val \\ Business Economics Department \\ Institute of Environmental Science and Technology \\ Universitat Autònoma de Barcelona \\ Lisa G.J. Drescher \\ Institute of Environmental Science and Technology \\ Universitat Autònoma de Barcelona
}

\begin{abstract}
The aim of this study is to analyze the effect exerted by corporate social strategies on (short-term and long-term) corporate financial performance (CFP). To this end, we use data on firms listed in the Stoxx Europe 600 index and Stoxx Europe Sustainability index from 2007 to 2010. On the sample data, we implement random and fixed effects panel data methodology corrected by heteroskedasticity, serial correlation and/or crosssectional dependence. The results obtained show that the implementation of CSR strategy, the level of economic development of the country and firm size determine CFP. In addition, the investment in research and development influences the return on assets while the company's financial slack affects the Tobin's Q. So, companies that contribute to sustainable development incur higher CFP.
\end{abstract}

Keywords: Corporate Social Responsibility; Sustainable development; Corporate Social Performance; Corporate Financial Performance; Panel data; European firms 


\section{Introduction}

The notion that businesses have some responsibility to society apart from merely fulfilling their economic and legal obligations has been lingering amongst academics for some time (Carroll and Shabana, 2010; Sarbutts, 2003). However, only recently - since the 1950s have the importance and empirical research of this topic increased dramatically. Many themes describing the relationship between the corporation and society as well as the natural environment have since been developed. The most commonly used term in the literature is Corporate Social Responsibility (CSR) (Montiel, 2008; Carroll and Shabana, 2010) followed by many alternative themes and terms such as Social Responsibility (SR), Corporate Citizenship, Corporate Sustainability and Corporate Social Performance (CSP) as well as Business Ethics and Stakeholder Management. One of the more notable debates regarding CSR is whether it is expedient for companies to value and act upon social demands.

Along with the development of different themes and terms, different perspectives from which corporations view their social and environmental activities, and ultimately different approaches to these activities, have blossomed as well (Porter and Kramer, 2006; Garriga and Melé, 2004). As opposed to the generic and marketing perspectives, Porter and Kramer (2006) propose a strategic way to implement CSR in one's business. If a firm combines its economic and CSR objectives with its core business strategy as a long-term commitment, then 'CSR can be much more than a cost, constraint, or charitable deed - it can be a source of opportunity, innovation, and competitive advantage' (Porter and Kramer, 2006, p. 80). However, most prevalent approaches to CSR are so detached from business that companies fail to achieve the greatest opportunities for society. This limitation, faced with the current economic downturn, implies that managers must develop highly focused and effective CSR actions after having identified which social issues matter most to the firm. By doing so, the firm can increase its own profit and strengthen its long-term competitiveness, as well as making a meaningful social impact and thereby achieving a win-win situation through the creation of the synergistic value known as shared value (Porter and Kramer, 2006; Ditlev-Simonson and Midtun, 2011).

Given all the above, the aim of this paper is to analyze whether firms that implement corporate social responsibility strategies achieve higher corporate financial performance than those that do not it. To do this, we structure the paper as follows: the next section presents a review of the literature on the link between Corporate Social Performance (CSP) and Corporate Financial Performance (CFP). Section 3 outlines our data sources, measures of variables and methodology used. In section 4 , the results of our regression models are discussed. Finally, some concluding remarks are provided.

\section{Literature review}

Nowadays, as stakeholders are showing an ever growing interest in the CSR of firms (Porter and Kramer (2006), Sá de Abreu (2009) and Waddock and Graves (1997)), the question of whether there is a relevant relationship between CSR and CFP has become an important theme for corporate management. This has aroused great interest among researchers, who have analyzed the relationship between CSP and CFP, but without reaching any real consensus, as shown by Beurden and Gossling (2008), Margolis et al (2007), Wu (2006), Margolis and Walsh (2003), Orlitzky et al (2003) and Griffin and Mahon (1997).

Thus, some authors, such as Stanwick and Stanwick (1998), Waddock and Graves (1997), Choi et al (2010), Inoue and Lee (2011) and Ioannou and Serafeim (2012), find a positive relationship between corporate social performance and corporate financial performance, 
arguing that (1) CFP leads to better CSP because more profitable companies have more resources to invest in socially responsible initiatives, (2) firms that implement corporate social responsibility (CSR) strategies could obtain: (a) better resources, attracting socially responsible consumers, alleviating the threat of regulation, soothing concerns from nongovernmental organizations and improving their reputation, (instrumental stakeholder theory), and (b) competitive advantage (resource based view theory), and (3) firms achieve greater legitimacy when attending to stakeholder pressures (institutional theory). Contrary to this, a negative relationship between CSP and CFP has been identified in a number of studies, such as Lee et al (2009) and Makni et al (2009). This line of research supports the view that corporate social responsibility activities only increase costs for firms, which is inconsistent with their main objective, namely to maximize shareholder wealth (traditional neo-classical theory).

The failure to reach a consensus on the relationship between CSP and CFP could be due to (1) the different ways CFP and CSR have been defined, (2) methodological issues and (3) differences in the characteristics of the samples used. Thus, previous literature uses different criteria to define CSP. Stanwick and Stanwick (1998), Cochran and Wood (1984) and Orlitzky (2001) use the firm's corporate reputation as a measure of CSP, finding a positive relation between CSP and CFP. Brammer and Millington (2008), Gallego-Alvarez (2012) and Fujii et al (2013) only take into account a specific component of CSP (corporate charitable giving and corporate environmental management, respectively) to analyze the aforementioned relationship, while Ruf et al (2001), Choi et al (2010), McWilliams and Siegel (2000) and Waddock and Graves (1997) use multidimensional CSR measures that, according to Griffin and Mahon (1997), offer an improvement on the largely perceptual data of the Fortune corporate reputation index. For this reason, in this study we use a multidimensional index (Stoxx Europe Sustainability index).

On the other hand, previous literature uses a broad range of measures of CFP that fall into two categories: accounting-based measures and market-based measures. The most extensively used measures of accounting profitability are Return On Equity (ROE) and Return On Assets (ROA), according to Margolis et al (2007), and were also used by Inoue and Lee (2011), Choi et al (2010), Lee et al (2009), Makni et al (2009) and Van der Laan et al (2008) to capture the short-term profitability of the firm. However, these measures could be inappropriate, as suggested by Davidson and Worrell (1990), since the relation between ROE and CSP could be influenced by the level of corporate debt, so applying DuPond's method, the ROE is defined as the product of the return on assets and the equity multiplier ratio from which a firm could increase its ROE by using more debt. On the other hand, the relation between ROA and CSP may be affected by the industry to which the firm belongs. Thus, the ROA can be defined as the product of the profit margin and the asset turnover ratio, which measures the ability to produce sales, which is not comparable across all industries.

As an alternative to accounting measures, market-based measures of company performance could be used. When doing so, one of the most common measures used in this field of research is stock returns, as shown by Margolis et al (2007). However, according to Cochran and Wood (1984), this measure fails to capture the total financial risk, which could produce contradictory results when researchers analyze data corresponding to different market cycles. To overcome this drawback, some authors, such as Lee et al (2009) and Choi et al (2010), introduce the financial risk variable to their model or change the stock return to risk-adjusted return, while others, such as Inoue and Lee (2011), Surroca et al (2010) and Choi et al (2010) use the Tobin's Q measure which 
does not require risk adjustment or normalization to compare Q across firms, as suggested by Li and Tallman (2011).

Using the above-mentioned measures, previous studies find that, in general, accountingbased measures appear to be more correlated with CSP than market-based measures (Orlitzky et al, 2003). This, according to Gentry and Shen (2010), could be because both types of financial performance measures reflect different dimensions of CFP: short-term profitability for accounting-based measures and future or long-term profitability for market-based measures.

On the other hand, overcoming the shortcomings of the above-mentioned financial performance measures, Brammer and Millington (2008), Wahba (2008), Lee et al (2009), Makni et al (2009), Choi et al (2010) and also McWilliams and Siegel (2000) have considered financial leverage influences, industry effects, differences in firm size, expenditure on research and development (R\&D) and country effects in their models, which has allowed them to overcome the misspecification problem that arises from omitting variables that are important determinants of profitability. In this respect, Davidson and Worrell (1990) point out that accounting data could be sensitive to leverage considerations; therefore not controlling for leverage differences could lead to inaccurate conclusions. Taking this consideration into account, Brammer and Millington (2008), Waddock and Graves (1997) and Wahba (2008) show that less leveraged firms invest more in CSR.

Different authors, such as Griffin and Mahon (1997) and Inoue and Lee (2011), point out that social issues change and vary for different industries because the stakeholders in each industry face different interests and degrees of activism regarding social issues. In this regard, Ioannou and Serafeim (2012) find that firms in more highly competitive industries show poorer social and environmental performance but better governance than those in less competitive industries.

According to Huang (2010), Brammer and Millington (2008) and Brik et al (2011), another factor that could influence the relationship between CSP and financial performance is firm size. Large firms have more resources to invest, which allows them to benefit from economies of scale, scope and learning, and thereby achieve better financial performance than smaller companies. It also allows them to meet their social obligations in order to preserve their competitive advantage, thus improving their corporate reputation and social performance.

R\&D investments made by firms could be an important determinant of profitability, as shown by McWilliams and Siegel (2000) and Brammer and Millington (2008), in that firms investing in R\&D seek a differentiation strategy to allow them to create competitive advantages and improve economic performance. On the other hand, according to Porter and Kramer (2006), firms that implement strategic CSR can obtain a source of competitive differentiation and improve their results. Therefore, a positive correlation between a firm's R\&D investment and CSP is expected. Thus, the omission of the R\&D factor from the analysis of the relationship between CSP and CFP could lead to an overestimation of the impact of CSP on CFP, according to McWilliams and Siegel (2000), which has driven Choi et al (2010), Makni et al (2009), Brammer and Millington (2008) and Ruf et al (2001) to consider the firm's R\&D intensity in their analyses.

Developed countries could provide the legal safeguards needed for economic growth, which would support the development of CSR, as shown by Ho et al (2012), who indicates that differences in CSP appear to be linked to the level of economic development. Congruent with this result, Usunier et al (2011) suggest that countries show differences in perceptions of the importance of social responsibility performance. For this reason, our study also examines this effect. 
Another reason why previous studies have not reached any real consensus could be methodological issues. This is exemplified by Choi et al (2010), McWilliams and Siegel (2000), Makni et al (2009), Ruf et al (2001), Stanwick and Stanwick (1998) and Waddock and Graves (1997) using ordinary least square regression and not taking into account the dynamic market environment or firm specific effects, which may produce biases and inconsistent estimators. To overcome these shortcomings, our study takes the aforesaid effects into account.

The characteristics of the samples used in previous literature are different. Inoue and Lee (2011) and Griffin and Mahon (1997) focus their research on one industry (tourism and chemical industries, respectively), while others, such as Choi et al (2010), Lee et al (2009) and Makni et al (2009), examine firms belonging to different industries. This could influence the results obtained because, as stated above, social and environmental impacts are different depending on the industry. For this reason, our study includes firms belonging to diverse industries, and controls for this factor.

Because it strives to improve the understanding of the CSP-CFP relationship, our study is broader than most of those existing in the current literature and seeks to move a step closer to articulating conclusive findings by overcoming the above-mentioned shortcomings.

Therefore, it is proposed that:

H1: Companies that perform well in terms of CSP also perform better financially.

\section{Research method}

\section{Sample and data collection}

To analyse the factors that affect the relationship between CSP and CFP, we have a database containing information relating to 600 firms for four consecutive fiscal years (from 2007-2010) composed of the Stoxx Europe 600 index provided by the Stoxx Limited Company. We consider firms included in the Stoxx Europe Sustainability index at the end of the year provided by the Stoxx Limited Company to present socially responsible behaviour regarding environmental, social and governance criteria. From the AMADEUS database we extracted information on the following for each year on the $31^{\text {st }}$ of December: the ROA, the ROE, total assets, long-term debt, current ratio, free cash flow, R\&D expenditure, ratio of market value of equity to book value of equity, the industry to which they belong, and the country in which their address for tax purposes is based. The gross national income of each country was obtained from The World Bank. We omit firms created after January $1^{\text {st }} 2008$, those dissolved during the period, or those with missing data for any of the years considered. So, our final sample includes data corresponding to 153 firms. Thus, according to Brown et al (1997), survival bias may appear as a result of excluding dissolved firms from the sample, or omitting, for methodological reasons, certain companies that existed in the period.

\section{Measures of Corporate Financial Performance}

Bearing in mind the available information, we consider the variables discussed below to be potential determinants of the CFP achieved by firms, since they are very similar to those used in the aforementioned previous literature. Given that Porter and Kramer (2006) state that firms that implement a strategic focus on CSR could generate a competitive advantage, which allows them to increase their own profit, we consider CFP to be a dependent variable while CSR is the independent variable. This causal relationship has 
also been observed by other authors, such as Callan and Thomas (2009), Brik et al (2011), Chen and Wang (2011), Choi et al (2010) and Hull and Rothenberg (2008), among others. Thus, for CFP, we follow the previous literature and use accounting-based and marketbased financial performance measures. As accounting-based measures, we use ROE and ROA which, according to Inoue and Lee (2011), capture different financial aspects of short-term profitability. Meanwhile, ROA, defined as the net income and total asset ratio, represents the relative profitability of asset utilization, and ROE, defined as net income and shareholder equity ratio, measures how efficiently a firm is utilizing the debt managed, as stated by Lee et al (2009). Our market-based performance measure is Tobin's Q, which captures aspects of long-term expected profitability and is measured by the ratio of market value of equity to book value of equity at the end of each year considered as in Choi et al (2010) and Lee et al (2009).

\section{Measures of Corporate Social Performance}

To measure CSP by European firms we use a dummy variable (CSP) as in McWilliams and Siegel (2000), based on the Stoxx Europe Sustainability index developed by the Stoxx Limited Company. This index, introduced in 2001, is a subset of the Stoxx Europe 600 Index, whose components are selected according to a systematic corporate sustainability assessment, based on long-term environmental, economic and social criteria. Each year, the Stoxx Europe Sustainability index selects the companies using the Sarasin Sustainability Matrix, which is a combination of the company and sector ratings. A firm is included in the aforementioned index if it obtains a positive rating. which depends on its position in the matrix. Taking this into account, our dummy variable takes the value of one if the firm is included in the latter index and a value of zero if it has not been qualified for the index.

\section{Control Variables}

The control variables have been selected on the basis of previous findings in the literature. Industry type, country, firm size, financial slack, risk, R\&D investment and year are used as control variables. Industry type is classified, according to the FTSE Group's categorization, as low, medium and high impact depending on the environmental impact of the company's operations. Thus, LIndusdry, MIndustry and HIndustry have a value of one if the firm is attributed to have low, medium and high activities of environmental impact, respectively, and a value of zero otherwise.

Given that previous studies, such as Ho et al (2012) and Usunier et al (2011), show that the level of economic development could determine investment in CSR, we introduce a dummy variable (Rich) to our model, that takes a value of one if the firm is in a country with higher gross national income than the average for the European countries considered, and a value of zero if it is not.

To control for the size of the company, as in Choi et al (2010), we include in our model the LSize variable, which is calculated as the natural logarithm of total assets. Lee et al (2009) point out that firms with financial slack are more likely to adopt CSR strategies than others with low levels of financial slack. For this reason, we include the current ratio (CR) in our model and the free cash flow (Cash) as proxies. Both of these were directly obtained from AMADEUS.

Following Callan and Thomas (2009) and Makni et al (2009), as a proxy of risk we use the ratio of the firm's long-term debt to total assets at the end of each year, this being represented by the Leverage variable. As in previous studies, such as Makni et al (2009), Choi et al (2010), Brammer and Millington (2008) and Ruf et al (2001), we take R\&D 
investment as a management preference variable, which is measured by the natural logarithm of R\&D expenditure at the end of each year (LRD).

Finally, given that Ducassy (2013) finds a significant positive relationship between Corporate Social Performance (CSP) and Corporate Financial Performance (CFP) at the beginning of the crisis (2007) which disappears when the crisis period is prolonged, we control for year effects by including two year dummy variables (Year2008 and Year2009), like Choi et al (2010), Inoue and Lee (2011) and Griffin and Mahon (1997), to distinguish the three years covered by this research, taking a value of one if the data on the company matches the date indicated and zero otherwise.

We verify that are no multicollinearity problems between independent variables using matrix correlation and running the variance inflation factor (VIF). The results obtained, which are shown in tables 1 and 2, indicate the absence of multicollinearity problems (Sharma and James, 1981).

\section{Modelling the Effect of CSP on CFP}

To analyze whether CSP is a determinant of CFP, we propose the following models, where the dependent variable is CFP measured by means of the ROE, ROA and Tobin's $\mathrm{Q}$ of each firm, respectively, and the independent variables are delayed by one year to avoid endogenous issues, as in Makni et al (2009) and Huang (2010):

\section{Model 1}

$\mathrm{CFP}_{\mathrm{i}, \mathrm{t}}=\alpha+\beta_{1} \mathrm{CSP}_{\mathrm{i}, \mathrm{t}-1}+\beta_{2}$ Year2008 $+\beta_{3}$ Year2009 $+\beta_{4}$ LIndus $_{\mathrm{i}, \mathrm{t}-1}+\beta_{5}$ MIndu $_{\mathrm{i}, \mathrm{t}-}$ ${ }_{1}+\quad \beta_{6} \mathrm{Rich}_{\mathrm{i}, \mathrm{t}-1}+\beta_{7} \mathrm{LSize}_{\mathrm{i}, \mathrm{t}-1}+\beta_{8} \mathrm{CR}_{\mathrm{i}, \mathrm{t}-1}+\beta_{9} \mathrm{LCash}_{\mathrm{i}, \mathrm{t}-1}+\beta_{10}$ LLeverage $_{\mathrm{i}, \mathrm{t}-1}+$ $\beta_{11} \operatorname{LRD}_{\mathrm{i}, \mathrm{t}-1}+\varepsilon_{\mathrm{i}, \mathrm{t}}[1]$

First, this model is estimated using the pooled OLS regression approach, which assumes that all the firms involved in the analysis are homogenous and the data is stationary, providing biased and inconsistent regression estimators when these assumptions are violated. To check this, the Breusch and Pagan Lagrangian multiplier test for random effects is conducted. The results show that firm-specific effects are statistically significant when we use ROE as a dependent variable (chi-squared (1):16.92; P-value: 0.000), ROA (chi-squared (1):8.80; P-value: 0.003) and Tobin's Q (chi-squared (1):153.25; P-value: 0.000 ). Thus, the random effect model provides a more efficient standard error estimator than the pooled OLS approach.

\section{Model 2}

$\mathrm{CFP}_{\mathrm{i}, \mathrm{t}}=\alpha_{\mathrm{i}}+\beta_{1} \mathrm{CSP}_{\mathrm{i}, \mathrm{t}-1}+\beta_{2}$ Year2008 $+\beta_{3}$ Year2009 $+\beta_{4}$ LIndus $_{\mathrm{i}, \mathrm{t}-1}+\beta_{5}$ MIndus $_{\mathrm{i}, \mathrm{t}-}$ ${ }_{1}+\quad \beta_{6} \mathrm{Rich}_{\mathrm{i}, \mathrm{t}-1}+\quad \beta_{7} \mathrm{LSize}_{\mathrm{i}, \mathrm{t}-1}+\quad \beta_{8} \mathrm{CR}_{\mathrm{i}, \mathrm{t}-1}+\beta_{9} \mathrm{LCash}_{\mathrm{i}, \mathrm{t}-1}+\beta_{10}$ LLeverage $_{\mathrm{i}, \mathrm{t}-1}+$ $\beta_{11}$ LRD $_{\mathrm{i}, \mathrm{t}-1}+\varepsilon_{\mathrm{i}, \mathrm{t}}[2]$

Where $\alpha_{\mathrm{i}}=\alpha+\mu_{\mathrm{i}}$, and $\mu_{\mathrm{i}}$ being a random variable is an unobserved individual-specific effect.

When the explicative and random variables are orthogonal, random effects estimators are more efficient than fixed effects estimators. In other cases, the estimators obtained by random effects regressions are biased and inconsistent, making it better to run fixed effects estimators. To test this assumption, we carry out the Hausman test, whose statistic shows that fixed effects estimators are more consistent than random effect estimators when we use ROE (chi-squared (8): 37.51; p-value: 0.000) and ROA (chi-squared (8): 33.18; p-value: 0.000) as a dependent variable, respectively, while random effect estimators are more efficient than fixed effects estimators when the dependent variable in 
our model is Tobin's Q (chi-squared (8): 8.98; p-value: 0.344). For this reason, we propose these models:

\section{Model 3}

$\operatorname{ROE}_{\mathrm{i}, \mathrm{t}}=\alpha_{\mathrm{i}}+\beta_{1} \mathrm{CSP}_{\mathrm{i}, \mathrm{t}-1}+\beta_{2}$ Year2008 $\beta_{3}$ Year2009 $+\beta_{4}$ LIndus $_{\mathrm{i}, \mathrm{t}-1}+\beta_{5}$ MIndus $_{\mathrm{i}, \mathrm{t}-}$ ${ }_{1}+\beta_{6} \mathrm{Rich}_{\mathrm{i}, \mathrm{t}-1}+\beta_{7} \mathrm{LSize}_{\mathrm{i}, \mathrm{t}-1}+\beta_{8} \mathrm{CR}_{\mathrm{i}, \mathrm{t}-1}+\beta_{9} \mathrm{LCash}_{\mathrm{i}, \mathrm{t}-1}+\beta_{10}$ LLeverage $_{\mathrm{i}, \mathrm{t}-1}+$ $\beta_{11} \mathrm{LRD}_{\mathrm{i}, \mathrm{t}-1}+\varepsilon_{\mathrm{i}, \mathrm{t}}[3]$

\section{Model 4}

ROA $_{i, t}=\alpha_{i}+\beta_{1}$ CSP $_{i, t-1}+\beta_{2}$ Year2008 $+\beta_{3}$ Year2009 $+\beta_{4}$ LIndus $_{i, t-1}+\beta_{5}$ MIndus $_{i, t-}$ ${ }_{1}+\quad \beta_{6} \mathrm{Rich}_{\mathrm{i}, \mathrm{t}-1}+\beta_{7} \mathrm{LSize}_{\mathrm{i}, \mathrm{t}-1}+\beta_{8} \mathrm{CR}_{\mathrm{i}, \mathrm{t}-1}+\beta_{9} \mathrm{LCash}_{\mathrm{i}, \mathrm{t}-1}+\beta_{10}$ LLeverage $_{\mathrm{i}, \mathrm{t}-1}+$ $\beta_{11} \operatorname{LRD}_{\mathrm{i}, \mathrm{t}-1}+\varepsilon_{\mathrm{i}, \mathrm{t}}[4]$

Where $\alpha_{\mathrm{i}}=\alpha+\mu_{\mathrm{i}}$, being $\mu_{\mathrm{i}}$ modelled as an individual-specific fixed effect.

\section{Model 5}

Tobin $_{i, t}=\alpha_{i}+\beta_{1}$ CSP $_{i, t-1}+\beta_{2}$ Year2008 $+\beta_{3}$ Year $2009+\beta_{4}$ LIndus $_{\mathrm{i}, \mathrm{t}-1}+\beta_{5}$ MIndus $_{\mathrm{i}, \mathrm{t}-}$ ${ }_{1}+\quad \beta_{6}$ Rich $_{\mathrm{i}, \mathrm{t}-1}+\quad \beta_{7}$ LSize $_{\mathrm{i}, \mathrm{t}-1}+\quad \beta_{8} \mathrm{CR}_{\mathrm{i}, \mathrm{t}-1}+\beta_{9} \mathrm{LCash}_{\mathrm{i}, \mathrm{t}-1}+\quad \beta_{10}$ LLeverage $_{\mathrm{i}, \mathrm{t}-1}+$ $\beta_{11} \operatorname{LRD}_{\mathrm{i}, \mathrm{t}-1}+\varepsilon_{\mathrm{i}, \mathrm{t}}[5]$

Where $\alpha_{\mathrm{i}}=\alpha+\mu_{\mathrm{i}}$, and $\mu_{\mathrm{i}}$ being a random variable is an unobserved individual-specific effect.

These fixed effects models assume that the errors are homoskedastic and spatially and temporally independent. However, O'Connell (1998) and Beck (2001) show that panel tests are considerably disturbed when the independence and homoskedasticity assumptions are violated. For this reason, like Horgos (2011), we test the hypotheses of homoskedasticity in the fixed effect model with the modified Wald test for groupwise heteroskedasticity. For model 3, this statistic is asymptotically distributed as chi-squared with 101 degrees of freedom. The sample value (chi-squared (153):3,100,000, p-value: 0.000 ) was higher than the critical value at $1 \%$ of significance; the null hypothesis of homoskedasticity is therefore rejected. The same occurs when the dependent variable is ROA (chi-squared (153):2,000,000, p-value: 0.000). This procedure is applied for our random effects model. The results obtained (chi-squared (153):1,800,000, p-value: 0.000 ) do not allow us to accept the null hypothesis of homoskedasticity.

According to Petersen (2009) and Fama and French (2002), the presence of serial correlation could underestimate the standard errors of the coefficients. For this reason, we also apply the serial correlation test to verify whether the data has first-order autocorrelation using the Wooldridge test (2002). The result of the aforementioned statistic for model 3 (F(1,152): 0.529 ;p-value: 0.468$)$ shows that we can accept the null hypotheses of no serial correlation. In contrast, when we apply the aforementioned test to models 4 and 5 the statistics obtained (for $(F(1,152)$ : 27.577 ;p-value: 0.000$)$ for model 4 and $(\mathrm{F}(1,152)$ : 11.418 ;p-value: 0.001$)$ for model 5 allow us to reject the null hypotheses of no serial correlation.

To verify the existence of cross-sectional independence, we implement the CD test proposed by Pesaran (2004), which is asymptotically consistent, as shown by Hsiao et al (2007). The results of Pesaran's test are: $C D=10.286$ ( $p$-value 0.000 ) for model $3, C D=$ 7.175 ( $\mathrm{p}$-value 0.006 ) for model 4 and $\mathrm{CD}=2.757$ ( $\mathrm{p}$-value 0.006 ) for model 5 , so we cannot accept the null hypotheses of cross-sectional independence.

Given that Reed and Ye (2011) show that when we use fixed effects estimations in the presence of heteroskedasticity, serial correlation and/or spatial correlation, we may obtain 
biased and inconsistent estimators, we use Panel Corrected Standard Error (PCSE), which performs better than Parks' Feasible Generalized Least Squares (FGLS) estimation proposed by Parks (1967) when the number of time periods is equal to or greater than the number of cross-sections, as in our sample ( Reed and Ye (2011)). On the other hand, to overcome the misspecification problems in model 5, we apply the White standard errors.

\section{Results}

Table 3 reports the estimation results of model 3, which introduces the ROE as a dependent variable, using pooled OLS, random effect, fixed effect estimators, Parks' feasible generalized least squares estimators and panel corrected standard error estimators. We can compare the estimators obtained using the different models described above, and find that these models present differences in terms of size and level of significance. This tells us that the non-compliance with the assumptions of independent and identically distributed (i.i.d.) errors in the traditional panel model and the existence of unobservable characteristics could lead us to either underestimate or overestimate the effect of certain variables on the CFP obtained by firms.

The results obtained using the panel corrected standard error approach, which allow us to correct misspecification problems, reveal that the implementation of a CSR strategy, the level of economic development of the country and firm size determine the ROE of the firm.

The CSP variable is positively and significantly related to the ROE of companies. Thus, companies with more socially responsible activities improve the shareholders' return, incurring higher CFP. This result coincides with those of Waddock and Graves (1997), Ruf et al (2001) and Callan and Thomas (2009), in support of stakeholder theory.

Similarly, there are significant differences in CFP depending on the level of economic development of the country where the firm has its address for tax purposes. Thus, the firms located in more developed countries obtain significantly better financial performance than other companies situated in less developed countries. This result coincides with the findings of Ho et al (2012). This could be due to the facts that developed countries have (1) a developed banking system that should enhance productivity or efficiency in the economy as pointed out by Odedokun (1996) and/or (2) more efficient technologies than less developed countries.

In contrast, there is a negative and significant relation between firm's volume of total assets and ROE, which could be due to larger firms having a more complex organizational structure, which is more formal and centralized than that of smaller firms, as stated by Daft (1995). This may produce inertia to change, decreasing their financial performance. This result contradicts with the previous empirical evidence in Callan and Thomas (2009) and Choi et al (2010).

The results for the ROA equations are presented in Table 4. They show that the estimators obtained using the different aforementioned models also present differences in terms of size and level of significance, as was the case for the ROE specification. Moreover, the factors that determine CFP are similar to those linked to the ROE specification, with one exception. We find a positive and significant relationship between the ROA variable and CSP and the classification of the country in which the headquarters are situated, while the relationship between ROA and firm size is negatively significant. Regarding the aforementioned difference between ROE and ROA specifications, R\&D investment has a significant and negative effect with regard to the ROA variable, which indicates that the benefits of investing in research and development do not compensate for the costs of doing so, in the short term. This finding is supported by Hart and Ahuja (1996). 
The findings associated with the Tobin's Q specification are shown in Table 5. In this case, the results show a positive and significant relationship between Tobin's Q and CSP and the level of development of the country where the headquarters are located. On the other hand, the relationship between Tobin's Q and firm size is negative, like in the findings for the ROE and ROA specifications. However, in this case we find a relationship between CFP and the financial slack of companies measured by the LCR and LCash variables. So, the results show that high q firms are more subject to free cash flow problems, in accordance with Jensen (1986), probably because the opportunities for investing the excess resources have been reduced by the financial crisis. The relation between Tobin's Q and the current ratio is significant and negative, which may indicate that available resources are not wisely invested, increasing the investors' perception of risk, as pointed out by Chen (2010).

\section{Conclusions and Limitations}

According to Porter and Kramer (2006), Sá de Abreu (2009) and Waddock and Graves (1997), stakeholders are becoming more and more concerned about the environmental and social consequences of firms' activities. This has aroused great interest among researchers, who have analyzed the relationship between CSP and CFP, but they have reached no real consensus, which could be due to (1) the different ways CFP and CSR have been defined, (2) methodological issues and (3) differences in the characteristics of the samples used. For this reason, our main objective is to analyze the effect of corporate social performance on corporate financial performance while overcoming the abovementioned shortcomings.

To this end, we obtain data relative to 153 firms in the Stoxx Europe 600 index for four consecutive fiscal years (from 2007-2010). For each firm, we have information regarding their inclusion in the Stoxx Europe Sustainability index at the end of the year provided by the Stoxx Limited Company and the ROA, the ROE, total assets, long-term debt, current ratio, free cash flow, R\&D expenditure, ratio of market value of equity to book value of equity, the industry to which they belong, and the country in which their address for tax purposes is based, provided by the AMADEUS database. The gross national income of each country was obtained from The World Bank.

On the sample data, we implement random and fixed effects panel data methodology corrected by heteroskedasticity, serial correlation and/or cross-sectional dependence. The results obtained show that the implementation of a CSR strategy determines CFP when we use ROE, ROA and Tobin's Q as a dependent variable. Thus, in the crisis period, companies that implemented CSR strategies obtained better financial performance than those that implemented traditional management strategies. Other variables that influence corporate financial performance, measured by ROE, ROA and Tobin's Q, are the level of development of the countries and the size of firms. Companies located in countries with a higher level of development obtain better financial performance than those located in countries with a lower level of development. This could be because the former own more resources and more advanced technology than the latter, from which the companies located in more developed countries can benefit. On the other hand, larger companies achieve poorer financial performance than smaller ones, which could be because the former have a more complex organizational structure, making it more difficult for them to adapt to the changing environment than it is for smaller companies.

Expenditure on research and development negatively affects the return on assets obtained by European firms. This could indicate that companies that implement R\&D strategies need to invest large amounts of money to order to obtain small profits or short-term losses. 
However, in the long term, this investment could allow them to obtain profits, albeit not significant, as shown by the relationship between expenditure on research and development and Tobin's Q. Another factor that influences Tobin's Q is the financial slack of the company, the value improving when the current ratio of the company is lower and the free cash flow is higher, which could indicate that the market is detecting that, in general, companies are not investing their available resources wisely, which could be due to the current economic situation reducing investment opportunities.

Given all of the above-mentioned, our recommendation is that firms should integrate social and environmental initiatives in their core business strategies to gain a competitive advantage that will enable them to improve their corporate financial performance as suggested by Porter and Kramer (2006). So, firms located in developing countries should invest their excess resources in: (1) the acquisition of existing technologies that improve their productivity growth, mitigating environmental damage as stated by Coad (2011), for innovative activity in terms of R\&D expenditure has a significantly negative relationship with return on asset and a weak positive association with market value (Tobin's Q) and (2) to align information technology for comprehensiveness strategy with business strategy to gain a competitive advantage, implementing market information systems, which could focus on the firm's markets and product sales, and/or interorganizational systems, which could improve stability with their customers and suppliers and control their socially and environmentally responsible business behaviour, and/or strategic decision support systems, which could contribute to high levels of internal and external analysis performed by the organization according to Sabherwal and Chan (2001) and Li and Tan (2013), which could reduce inertia to change and make more dynamic the decision-making processes of large firms.

On the other hand, given that developed countries could have more efficient technologies, firms located in such countries should implement a product leadership business strategy, which could focus on product differences, discovery, innovation and flexibility of the production methods that produce competitive advantage and environmental and social benefits (Porter and Kramer, 2006). To improve quality and service and to maintain flexibility, firms' business strategies should be to align with their workforce and information systems and technology, as suggested by Wang and Verma (2012) and Sabherwal and Chan (2001).

For this reason, firms in developed countries should: (1) integrate human resource issues with their business strategy (Brewster, 2004) investing their excess resources in implementing human resource management systems -managed by a human resources professional who should be on the main company board (Jones, 1996)-, to allow them to attract and retain the best employees and to understand their demands as stakeholders who control critical supplies, products and services to adapt their management practices and ensure these stakeholders' support (Wang and Verma, 2012) and (2) to align information technology for flexibility strategy with business strategy to gain a competitive advantage, implementing market information systems, which could focus on the firm's markets and product sales, and/or strategic decision support systems, which could contribute to proactivity by helping the firm to make strategic decisions quickly and effectively, making the decision-making process in large firms more dynamic, as suggested by Sabherwal and Chan (2001) and Li and Tan (2013).

To support the integration of these social and environmental issues in firms' business operations and core strategies, the European Commission promotes public policies on Corporate Social Responsibility using a set of instruments consisting of financial, legal, partnering, informational and hybrid governance tools as shown by Steurer et al (2012), Steurer (2011) and Sarkar (2008). In this sense, our findings could be useful in the 
development of the European Union corporate governance framework initiated by the European Commission, for our findings show that it could be useful for firms to have a diversified board, selecting its members on the basis of such criteria as professional qualifications, experience, merit, the personal qualities of the candidate, independence and regional backgrounds, thereby giving the firm a range of values, views and competencies to adopt social and environmental initiatives into its core business strategy and align workforce and information systems with business strategy. The composition of the board should be disclosed and justified by the firm, and it should be adapted to its characteristics (size, level of internationalization and so on). The financial performance obtained by the board should be evaluated by an external facilitator each year, and revealed to the stakeholders together with the policy risk decided for the whole firm by the board of directors, whose payment policy should be voted by shareholders, which could increase shareholder engagement and the degree of information transparency.

Finally, there are two limitations to our study that other future work might seek to address. First, we do not know the score for each category of CSR that Stoxx Limited Company gives to each firm. Therefore, we can only analyze the overall effect of CSR activities and not the effect of each aspect of social corporate performance on financial performance. Second, our model does not take into account the effect that other factors (organizational structure, geographical diversification of firm, among others) may exert on the relationship between CSP and CFP.

\section{References}

Beck N. 2001. Time-Series-Cross-Section Data: What Have We Learned in the Past Few Years? Annual Review of Political Science 4: 271-293.

Beurden PV, Gossling T. 2008. The worth of values - a literature review on the relation between corporate social and financial performance. Journal of Business Ethics 82: 407424.

Bowen H. 1953. Social Responsibilities of the Businessman. Harper: New York.

Brammer S, Millington A. 2008. Does it pay to be different? An analysis of the relationship between corporate social and financial performance. Strategic Management Journal 29: 1325-1343.

Brewster C. 2004. European perspectives on human resource management. Human Resource Management Review 14: 365-382.

Brik AB, Rettab B, Mellahi K. 2011. Market orientation, corporate social responsibility and business performance. Journal of Business Ethics 99: 307-324.

Brown SJ, Goetzmann W, Ibbotson RG, Ross SA. 1992. Survivorship bias in performance studies. Review of Financial Studies 5: 553-580.

Callan SJ, Thomas JM. 2009. Corporate financial performance and corporate social performance: an update and reinvestigation. Corporate Social Responsibility and Environmental Management 16: 61-78.

Carroll AB. 1979. A three-dimensional model of corporate performance. Academy of Management Review 4: 497-505.

Carroll AB. 1999. Corporate Social Responsibility: Evolution of a Definitional Construct. Business \& Society 38: 268-295.

Carroll AB, Shabana KM. 2010. The business case for corporate social responsibility: A review of concepts, research and practice. International Journal of Management Reviews 12: $85-105$.

Chen H, Wang X. 2011. Corporate social responsibility and corporate financial performance in China: an empirical research from Chinese firms. Corporate Governance 11: $361-370$. 
Chen MH. 2010. The economy, tourism growth and corporate performance in the Taiwanese hotel industry. Tourism Management 31: 665-675.

Choi JS, Kwak YN, Choe C. 2010. Corporate social responsibility and corporate financial performance: evidence from Korea. Australian Journal of Management 35: 291-311.

Coad A. 2011. Appropriate business strategy for leaders and laggards. Industrial and Corporate Change 20: 1049-1079.

Cochran PL, Wood RA. 1984. Corporate social responsibility and financial performance. Academy of Management Journal 27: 42-56.

Daft RL. 1995. Organization Theory and Design. 5th Edition. West Publishing Company: Minneapolis, St. Paul, MN.

Davidson W, Worrell DL. 1990. A comparison and test of the use of accounting and stock market data in relating corporate social responsibility and financial performance. Akron Business and Economic Review 21: 7-19.

Ditlev-Simonsen CD, Midttun A. 2011. What motivates managers to pursue corporate responsibility? A survey among key stakeholders. Corporate Social Responsibility and Environmental Management 18: 25-38.

Ducassy I. 2013. Does Corporate Social Responsibility Pay Off in Times of Crisis? An Alternate Perspective on the Relationship between Financial and Corporate Social Performance. Corporate Social Responsibility and Environmental Management 20: 157167.

Fama EF, French K. 2002. Testing Tradeoff and Pecking Order Predictions about Dividends and Debt. Review of Financial Studies 15: 1-33.

Frederick WC. 2006. Corporation, Be Good! The Story of Corporate Social Responsibility. Dog Ear Publishing: Indianapolis.

Fujii H, Iwata K, Kaneko S, Managi S. 2013. Corporate Environmental and Economic Performance of Japanese Manufacturing Firms: Empirical Study for Sustainable Development. Business Strategy and the Environment 22: 187-201.

Gallego-Alvarez I. 2012. Impact of $\mathrm{CO}_{2}$ Emission Variation on Firm Performance. Business Strategy and the Environment 21: 435-454.

Garriga E, Melé D. 2004. Corporate Social Responsibility Theories: Mapping the Territory. Journal of Business Ethics 53: 51-71.

Gentry RJ, Shen W. 2010. The relationship between accounting and market measures of firm financial performance: how strong is it? Journal of managerial issues 22: 514-530.

Griffin JJ, Mahon JF. 1997. The corporate social performance and corporate financial performance debate. Business and Society 36: 5-31.

Hart S, Ahuja G. 1996. Does it pay to be green? An empirical examination of the relationship between emission reduction and firm performance. Business Strategy and the Environment 5: 30-37.

Ho FN, Wang HMD, Vitell SJ. 2012. A global analysis of corporate social performance: the effects of cultural and geographic environments. Journal of Business Ethics 107: 423433.

Horgos D. 2011. International outsourcing and the sector bias: new empirical evidence. Review of International Economics 19: 232-244.

Hsiao C, Pesaran MH, Pick A 2007. Cross section independence for nonlinear panel data models. IZA Discussion Paper Series No. 2756.

Huang CJ. 2010. Corporate governance, corporate social responsibility and corporate performance. Journal of Management and Organization 16: 1-13.

Hull CE, Rothenberg S. 2008. Firm performance: the interactions of corporate social performance with innovation and industry differentiation. Strategic Management Journal 29: 781-789. 
Ioannou I, Serafeim G. 2012. What drives corporate social performance? International evidence from social, environmental and governance scores. Journal of International Business Studies (Forthcoming).

Inoue Y, Lee S. 2011. Effects of different dimensions of corporate social responsibility on corporate financial performance in tourism-related industries. Tourism Management 32: $790-804$.

Jensen M. 1986. Agency Costs of Free Cash Flow, Corporate Finance and Takeovers. American Economic Review 76: 323-329.

Jones O. 1996. Strategic HRM: The implications for pharmaceutical R\&D. Technovation 16: 21-32.

Lee DD, Faff RW, Langfield SK. 2009. Revisiting the vexing question: does superior corporate social performance lead to improved financial performance. Australian Journal of Management 34: 21-49.

Lee MP. 2008. A review of the theories of corporate social responsibility: its evolutionary path and the road ahead. International Journal of Management Reviews 10: 53-73.

Li S, Tallman B. 2011. MNC Strategies, exogenous shocks and performance outcomes, Strategic Management Journal 32: 1119-1127.

Li Y, Tan CH. 2013. Matching business strategy and CIO characteristics: The impact on organizational performance. Journal of Business Research 66: 248-259.

Makni R, Francoeur C, Bellavance F. 2009. Causality between corporate social performance and financial performance: evidence from Canadian firms. Journal of Business Ethics 89: 409-422.

Margolis JD, Walsh JP. 2003. Misery loves companies: rethinking social initiatives by business. Administrative Science Quarterly 48: 268-305.

Margolis JD, Elfenbein HA, Walsh JP. 2007. Does it pay to be good? A meta-analysis and redirection of research on the relationship between corporate social and financial performance. Working Paper: Harvard Business School.

McGuire J. 1963. Business and Society. McGraw-Hill: New York.

McWilliams A, Siegel D. 2000. Corporate social responsibility and financial performance: correlation or misspecification? Strategic Management Journal 21: 603609.

Montiel I. 2008. Corporate Social Responsibility and Corporate Sustainability: Separate Pasts, Common Futures. Organization \& Environment 21: 245-269.

O'Connell P. 1998. The overvaluation of purchasing power parity Journal of International Economics 44: 1-19.

Odedokun, MO. 1996. International evidence on the effects of directed credit programmes on efficiency of resource allocation in developing countries: the case of development bank lendings. Journal of Development Economics 48: 449-460.

Orlitzky M, Schmidt FL, Rynes SL. 2003. Corporate social and financial performance: a meta-analysis. Organization Studies 24: 403-441.

Orlitzky M. 2001. Does firm size confound the relationship between corporate social performance and -firm financial performance? Journal of Business Ethics 33: 167-180.

Parks R. 1967. Efficient estimation of a system of regression equations when disturbances are both serially and contemporaneously correlated. Journal of the American Statistical Association 62: 500-9.

Pesaran MH. 2004. General diagnostic tests for cross section dependence in panels. Cambridge Working Paper in Economics 0435.

Petersen M. 2009. Estimating Standard Errors in Finance Panel Data Sets: Comparing Approaches. The Review of Financial Studies 22: 435-480. 
Porter ME, Kramer MR. 2006. Strategy and Society: The link between competitive advantage and corporate social responsibility. Harvard Business Review 84: 78-92.

Reed WR, Ye H. 2011. Which panel data estimator should I use? Applied Economics 43: 985-1000.

Ruf B, Muralidhar K, Brown RM, Janney JJ, Paul K. 2001. An empirical investigation of the relationship between change in corporate social performance and financial performance: a stakeholder theory perspective. Journal of Business Ethics 32: 143-156.

Sá de Abreu MC. 2009. How to Define an Environmental Policy to Improve Corporate Sustainability in Developing Countries. Business Strategy and the Environment 18:542556.

Sabherwal R, Chan YE. 2001. Alignment Between Business and IS Strategies: A Study of Prospectors, Analyzers and Defenders. Information Systems Research 12:11-33.

Sarbutts N. 2003. Can SMEs "do" CSR? A Practitioner's View of the Ways Small- and Medium-Sized Enterprises are Able to Manage Reputation Through Corporate Social Responsibility. Journal of Communication Management 7: 340-347.

Sarkar R. 2008. Public Policy and Corporate Environmental Behaviour: a Broader View. Corporate Social Responsibility and Environmental Management 15: 281-297.

Sethi SP. 1975. Dimensions of corporate social performance: an analytical framework. California Management Review 17: 58-64.

Sharma S, James WL. 1981. Latent root regression: an alternate procedure for estimating parameters in the presence of multicollinearity. Journal of Marketing Research 18: 154161.

Stanwick A, Stanwick D. 1998. The relationship between corporate social performance, and organizational size, financial performance, and environmental performance: an empirical examination. Journal of Business Ethics 17: 195-204.

Steurer R. 2011. Soft Instruments, Few Networks: How 'New Governance' Materializes in Public Policies on Corporate Social Responsibility Across Europe. Environmental Policy and Governance 21: 270-290.

Steurer R, Martinuzzi A, Margula S. 2012. Public Policies on CSR in Europe: Themes, Instruments and Regional Differences. Corporate Social Responsibility and Environmental Management 19: 206-227.

Surroca J, Tribo JA, Waddock S. 2010. Corporate responsibility and financial performance: the role of intangible resources. Strategic Management Journal 31: 463490.

Usunier JC, Furrer O, Furrer-Perrinjaquet A. 2011. The perceived trade-off between corporate social and economic responsibility: a cross-national study. International Journal of Cross Cultural Management 11: 279-302.

Van der Laan G, Van Ees H, Van Witteloostuijn A. 2008. Corporate social and financial performance: an extended stakeholder theory, and empirical test with accounting measures. Journal of Business Ethics 79: 299-310.

Vogel DJ. 2005. Is there a market for virtue? The business case for Corporate Social Responsibility. California Management Review 47: 19-45.

Waddock SA, Graves SB. 1997. The Corporate Social Performance-Financial Performance Link. Strategic Management Journal 18: 303-319.

Wahba H. 2008. Exploring the moderating effect of financial performance on the relationship between corporate environmental responsibility and institutional investors: some Egyptian evidence. Corporate Social Responsibility and Environmental Management 15: 361-371. 
Wang J, Verma A. 2012. Explaining organizational responsiveness to work-life balance issues: the role of business strategy and high performance work systems. Human Resource Management 51: 407-432.

Wood DJ. 1991. Corporate social performance revisited. Academy of Management Review 16: 691-718.

Wooldridge JM. 2002. Econometric Analysis of Cross Section and Panel Data. MIT Press: Cambridge, MA.

Wu ML. 2006. Corporate social performance, corporate financial performance, and firm size: a meta-analysis. Journal of American Academy of Business 8: 163-171. 


\begin{tabular}{|c|c|c|c|c|c|c|c|c|c|c|c|c|c|c|c|c|c|c|c|}
\hline & VIF & CSPt-1 & & roe & & roa & & Tobin's Q & & Year2008 & & Year2009 & Year2010 & LIndust-1 & & MIndust-1 & & HIndust-1 & \\
\hline CSPt-1 & 1.19 & 1.00 & & & & & & & & & & & & & & & & & \\
\hline roe & & 0.08 & & 1.00 & & & & & & & & & & & & & & & \\
\hline roa & & 0.07 & & 0.82 & $*$ & 1.00 & & & & & & & & & & & & & \\
\hline tobin & & 0.01 & & 0.39 & $*$ & 0.39 & $*$ & 1.00 & & & & & & & & & & & \\
\hline Year2008 & 1.35 & -0.01 & & -0.02 & & -0.03 & & -0.11 & $*$ & 1.00 & & & & & & & & & \\
\hline Year2009 & 1.35 & 0.00 & & -0.10 & $*$ & -0.10 & $*$ & -0.01 & & -0.50 & $*$ & 1.00 & & & & & & & \\
\hline Year2010 & & 0.00 & & 0.11 & $*$ & 0.14 & $*$ & 0.12 & $*$ & -0.50 & $*$ & -0.50 & 1.00 & & & & & & \\
\hline LIndust-1 & 1.09 & -0.04 & & -0.09 & & -0.05 & & 0.02 & & 0.00 & & 0.00 & 0.00 & 1.00 & & & & & \\
\hline MIndust-1 & 1.10 & 0.05 & & 0.02 & & 0.02 & & 0.05 & & 0.00 & & 0.00 & 0.00 & -0.19 & 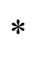 & 1.00 & & & \\
\hline HIndust-1 & & 0.00 & & 0.05 & & 0.03 & & -0.05 & & 0.00 & & 0.00 & 0.00 & -0.67 & $*$ & $-0.61 *$ & $*$ & 1.00 & \\
\hline Richt-1 & 1.11 & 0.12 & $*$ & 0.12 & $*$ & 0.16 & $*$ & 0.20 & $*$ & 0.00 & & 0.00 & 0.00 & -0.07 & & -0.10 & $*$ & 0.14 & $*$ \\
\hline LSizet-1 & 3.77 & 0.34 & $*$ & -0.14 & $*$ & -0.21 & $*$ & -0.36 & $*$ & -0.02 & & 0.01 & 0.02 & -0.03 & & $0.09 *$ & $*$ & -0.05 & \\
\hline CRt-1 & 1.24 & -0.18 & $*$ & 0.01 & & 0.15 & $*$ & 0.08 & & -0.02 & & -0.05 & 0.07 & -0.12 & $*$ & 0.07 & & 0.04 & \\
\hline LCasht-1 & 3.42 & 0.31 & $*$ & -0.09 & & -0.08 & & -0.17 & $*$ & -0.04 & & -0.02 & 0.06 & 0.00 & & 0.10 & $*$ & -0.07 & \\
\hline LLeveraget-1 & 1.21 & 0.04 & & -0.04 & & -0.20 & $*$ & -0.13 & $*$ & -0.05 & & 0.02 & 0.03 & 0.00 & & 0.09 & & -0.06 & \\
\hline LRDt-1 & 1.15 & 0.04 & & -0.08 & & -0.09 & $*$ & -0.01 & & -0.02 & & 0.01 & 0.01 & -0.15 & $*$ & $-0.10 *$ & $*$ & 0.20 & $*$ \\
\hline
\end{tabular}

\begin{tabular}{|c|c|c|c|c|c|c|c|}
\hline & Richt-1 & & LSizet-1 & & CRt-1 & LCasht-1 & LLeveraget-1 \\
\hline Richt-1 & 1.00 & & & & & & \\
\hline LSizet-1 & -0.08 & & 1.00 & & & & \\
\hline CRt-1 & 0.13 & $*$ & -0.28 & $*$ & 1.00 & & \\
\hline LCasht-1 & 0.02 & & 0.79 & $*$ & -0.08 & 1.00 & \\
\hline LLeveraget-1 & -0.10 & $*$ & 0.19 & $*$ & -0.14 & -0.06 & 1.00 \\
\hline LRDt-1 & 0.17 & $*$ & 0.21 & $*$ & 0.05 & 0.23 & -0.03 \\
\hline
\end{tabular}

Table 1. Correlation Matrix for Regression Variables. ***Significant at the $1 \%$ level, ** Significant at the $5 \%$ level, $*$ Significant at the $10 \%$ level. 
Table 2

Dependent and independent variable descriptive statistics for variables used during testing

\begin{tabular}{|l|r|r|r|r|r|}
\hline VARIABLE & \multicolumn{1}{|c|}{ MEAN } & MEDIAN & STD DEV & MIN & \multicolumn{1}{c|}{ MAX } \\
\hline N. firms & 153 & & & & \\
\hline ROE & 15.91 & 15.34 & 19.08 & -153.03 & 191.31 \\
\hline ROA & 6.68 & 5.95 & 7.73 & -71.82 & 62.20 \\
\hline TOBIN & 2.44 & 2.03 & 1.69 & 0.22 & 16.13 \\
\hline Size* & $20,146.19$ & $5,297.20$ & $34,160.57$ & 108.53 & $262,964.00$ \\
\hline CR & 1.67 & 1.46 & 0.89 & 0.11 & 7.28 \\
\hline Cash* & $1,445.13$ & 437.35 & $2,629.58$ & 0.74 & $20,604.50$ \\
\hline Leverage & 0.18 & 0.17 & 0.14 & 0 & 0.68 \\
\hline RD* & 500.07 & 61.83 & $1,711.55$ & 0 & $22,967.53$ \\
\hline
\end{tabular}

Panel A: Continuous variable. Descriptive statistics. Expressed in millions of euros*

\begin{tabular}{|l|c|r|r|}
\hline VARIABLE & CODE & FREQUENCY & $\begin{array}{c}\text { PERCENTAGE } \\
\text { BY CATEGORY }\end{array}$ \\
\hline \multirow{2}{*}{ CSP $_{\text {t-1 }}$} & 0 & 471 & 76.96 \\
\multirow{2}{*}{ LIndust $t$-1 } & 1 & 141 & 23.04 \\
\hline \multirow{2}{*}{ MIndust-1 } & 0 & 508 & 83.01 \\
& 1 & 104 & 16.99 \\
\hline \multirow{2}{*}{ HIndust-1 } & 0 & 524 & 85.62 \\
\multirow{2}{*}{ Rich $_{\text {t-1 }}$} & 1 & 88 & 14.38 \\
\hline
\end{tabular}

Panel B: Dichotomous variables. Descriptive statistics 


\begin{tabular}{|c|c|c|c|c|c|c|c|c|c|c|}
\hline \multirow[b]{2}{*}{$\mathrm{CSP}_{\mathrm{t}-1}$} & \multicolumn{2}{|c|}{$\begin{array}{l}\text { Pooled OLS } \\
\text { coeficient }\end{array}$} & \multicolumn{2}{|c|}{$\begin{array}{c}\text { Random } \\
\text { Effects Coef. }\end{array}$} & \multicolumn{2}{|c|}{$\begin{array}{l}\text { Fixed Effects } \\
\text { Coef. }\end{array}$} & \multicolumn{2}{|c|}{ GLS Coef. } & \multicolumn{2}{|c|}{ pcse coef. } \\
\hline & $\begin{array}{r}5.060 \\
(2.276)\end{array}$ & $* *$ & $\begin{array}{r}3.688 \\
(2.586)\end{array}$ & & $\begin{array}{l}-6.925 \\
(4.711)\end{array}$ & & $\begin{array}{r}2.912 \\
(0.732)\end{array}$ & $* * *$ & $\begin{array}{r}5.060 \\
(1.956)\end{array}$ & $* *$ \\
\hline Year2008 & $\begin{array}{l}-3.864 \\
(2.127)\end{array}$ & $*$ & $\begin{array}{r}-3.749 \\
(1.874)\end{array}$ & $* *$ & $\begin{array}{l}-5.331 \\
(1.925)\end{array}$ & $* * *$ & $\begin{array}{r}-0.873 \\
(0.589)\end{array}$ & & $\begin{array}{r}-3.864 \\
(2.109)\end{array}$ & $*$ \\
\hline Year2009 & $\begin{array}{l}-5.769 \\
(2.126)\end{array}$ & $* * *$ & $\begin{array}{l}-5.695 \\
(1.872)\end{array}$ & $* * *$ & $\begin{array}{l}-6.172 \\
(1.864)\end{array}$ & $* * *$ & $\begin{array}{r}-3.008 \\
(0.590)\end{array}$ & $* * *$ & $\begin{array}{l}-5.769 \\
(2.104)\end{array}$ & $* * *$ \\
\hline LIndust-1 & $\begin{array}{l}-4.952 \\
(2.401)\end{array}$ & $* *$ & $\begin{array}{l}-5.189 \\
(2.965)\end{array}$ & $*$ & omitted & & $\begin{array}{r}-3.384 \\
(0.881)\end{array}$ & $* * *$ & $\begin{array}{r}-4.952 \\
(3.261)\end{array}$ & \\
\hline MInduSt-1 & $\begin{array}{r}1.298 \\
(2.585)\end{array}$ & & $\begin{array}{r}1.231 \\
(3.190)\end{array}$ & & omitted & & $\begin{array}{r}0.239 \\
(0.697)\end{array}$ & & $\begin{array}{r}1.298 \\
(2.952)\end{array}$ & \\
\hline Rich $_{t-1}$ & $\begin{array}{r}5.761 \\
(2.696)\end{array}$ & $* *$ & $\begin{array}{r}6.003 \\
(3.319)\end{array}$ & $*$ & omitted & & $\begin{array}{r}4.488 \\
(0.879)\end{array}$ & $* * *$ & $\begin{array}{r}5.761 \\
(2.543)\end{array}$ & $* *$ \\
\hline LSize $_{t-1}$ & $\begin{array}{c}-2.754 \\
(1.089)\end{array}$ & $* *$ & $\begin{array}{l}-3.450 \\
(1.282)\end{array}$ & $* * *$ & $\begin{array}{l}-29.500 \\
(5.444)\end{array}$ & $* * *$ & $\begin{array}{l}-2.778 \\
(0.400)\end{array}$ & $* * *$ & $\begin{array}{r}-2.754 \\
(1.395)\end{array}$ & $* *$ \\
\hline $\mathbf{C R}_{\mathrm{t}-1}$ & $\begin{array}{l}-1.342 \\
(1.081)\end{array}$ & & $\begin{array}{l}-1.667 \\
(1.242)\end{array}$ & & $\begin{array}{l}-3.158 \\
(2.356)\end{array}$ & & $\begin{array}{l}-1.001 \\
(0.339)\end{array}$ & $* * *$ & $\begin{array}{l}-1.342 \\
(0.962)\end{array}$ & \\
\hline $\operatorname{LCash}_{t-1}$ & $\begin{array}{r}0.679 \\
(0.989)\end{array}$ & & $\begin{array}{r}1.279 \\
(1.150)\end{array}$ & & $\begin{array}{r}1.255 \\
(2.524)\end{array}$ & & $\begin{array}{r}1.056 \\
(0.370)\end{array}$ & $* * *$ & $\begin{array}{r}0.679 \\
(1.477)\end{array}$ & \\
\hline LLeverage $_{t-1}$ & $\begin{array}{r}-0.675 \\
(6.818)\end{array}$ & & $\begin{array}{r}4.725 \\
(7.946)\end{array}$ & & $\begin{array}{r}54.252 \\
(17.767)\end{array}$ & $* * *$ & $\begin{array}{r}1.471 \\
(2.284)\end{array}$ & & $\begin{array}{r}-0.675 \\
(8.730)\end{array}$ & \\
\hline $\mathbf{L R D}_{\mathrm{t}-1}$ & $\begin{array}{r}-0.248 \\
(0.159)\end{array}$ & & $\begin{array}{r}-0.260 \\
(0.194)\end{array}$ & & $\begin{array}{r}-0.220 \\
(1.066)\end{array}$ & & $\begin{array}{c}-0.204 \\
(0.046)\end{array}$ & $* * *$ & $\begin{array}{r}-0.248 \\
(0.155)\end{array}$ & \\
\hline Intercept & $\begin{array}{r}71.313 \\
(14.624)\end{array}$ & $* * *$ & $\begin{array}{r}75.115 \\
(17.700)\end{array}$ & $* * *$ & $\begin{array}{r}660.371 \\
(124.069)\end{array}$ & $* * *$ & $\begin{array}{l}61.278 \\
(4.528)\end{array}$ & $* * *$ & $\begin{array}{r}71.313 \\
(14.096)\end{array}$ & $* * *$ \\
\hline $\begin{array}{l}\text { R-squared } \\
\text { R-adjusted }\end{array}$ & & $\begin{array}{l}0.055 \\
0.078\end{array}$ & & 0.075 & & 0.019 & & & & 0.078 \\
\hline N. Observations & & 459 & & 459 & & 459 & & 459 & & 459 \\
\hline
\end{tabular}

Table 3. Regression Estimates-Dependent Variable ROE. Standard errors are given in parentheses. ${ }^{* *}$ Significant at the $1 \%$ level, $* *$ Significant at the $5 \%$ level, $*$ Significant at the $10 \%$ level 


\begin{tabular}{|c|c|c|c|c|c|c|c|c|c|c|}
\hline \multirow{3}{*}{$\operatorname{CSP}_{t-1}$} & \multicolumn{2}{|c|}{$\begin{array}{l}\text { Pooled OLS } \\
\text { coeficient }\end{array}$} & \multicolumn{2}{|c|}{$\begin{array}{c}\text { Random } \\
\text { Effects Coef. }\end{array}$} & \multicolumn{2}{|c|}{$\begin{array}{l}\text { Fixed Effects } \\
\text { Coef. }\end{array}$} & \multicolumn{2}{|c|}{ GLS Coef. } & \multicolumn{2}{|c|}{ pcse coef. } \\
\hline & 2.498 & $* * *$ & 2.178 & $* *$ & -1.092 & & 1.702 & $* * *$ & 2.138 & $* * *$ \\
\hline & $(0.893$ & & $(0.992)$ & & (1.923) & & $(0.344)$ & & $(0.791)$ & \\
\hline \multirow{2}{*}{ Year2008 } & -1.917 & $* *$ & -1.880 & $* *$ & -2.229 & $* * *$ & -1.130 & $* * *$ & -1.809 & $* *$ \\
\hline & $(0.834$ & & $(0.761)$ & & $(0.786)$ & & $(0.198)$ & & $(0.801)$ & \\
\hline \multirow{2}{*}{ Year2009 } & -2.518 & $* * *$ & -2.499 & $* * *$ & -2.657 & $* * *$ & -1.721 & $* * *$ & -2.439 & $* * *$ \\
\hline & $(0.834$ & & $(0.760)$ & & $(0.761)$ & & $(0.173)$ & & $(0.722)$ & \\
\hline \multirow{2}{*}{ LIndust-1 } & -0.817 & & -0.905 & & omitted & & -0.484 & & -1.064 & \\
\hline & $(0.942$ & & $(1.110)$ & & & & $(0.411)$ & & $(1.342)$ & \\
\hline \multirow{2}{*}{ MInduSt-1 } & 0.593 & & 0.569 & & omitted & & 0.103 & & 0.087 & \\
\hline & $(1.014$ & & (1.194) & & & & $(0.293)$ & & $(2.085)$ & \\
\hline \multirow{2}{*}{ Richt-1 $_{t}$} & 2.682 & $* *$ & 2.754 & $* *$ & omitted & & 2.602 & $* * *$ & 2.699 & $* *$ \\
\hline & $(1.057$ & & $(1.244)$ & & & & $(0.431)$ & & (1.061) & \\
\hline \multirow{2}{*}{ LSize $_{t-1}$} & -1.328 & $* * *$ & -1.579 & $* * *$ & -10.122 & $* * *$ & -1.476 & $* * *$ & -1.808 & $*$ \\
\hline & $(0.427$ & & $(0.487)$ & & $(2.222)$ & & $(0.159)$ & & $(0.924)$ & \\
\hline \multirow{2}{*}{$\mathbf{C R}_{\mathrm{t}-1}$} & 0.474 & & 0.305 & & -1.345 & & 0.547 & $* * *$ & 0.326 & \\
\hline & $(0.424$ & & $(0.475)$ & & $(0.962)$ & & $(0.126)$ & & $(0.424)$ & \\
\hline \multirow{2}{*}{$\operatorname{LCash}_{\mathrm{t}-1}$} & 0.434 & & 0.653 & & 1.405 & & 0.550 & $* * *$ & 0.933 & \\
\hline & $(0.388$ & & $(0.438)$ & & $(1.030)$ & & $(0.149)$ & & (1.027) & \\
\hline \multirow{2}{*}{ LLeverage $_{t-1}$} & -7.555 & $* * *$ & -5.642 & $*$ & 19.622 & $* * *$ & -3.834 & $* * *$ & -3.944 & \\
\hline & $(2.674$ & & $(3.025)$ & & (7.253) & & $(0.928)$ & & $(3.752)$ & \\
\hline \multirow{2}{*}{$\mathbf{L R D}_{\mathrm{t}-1}$} & -0.125 & $* *$ & -0.128 & $*$ & -0.175 & & -0.008 & & -0.139 & $*$ \\
\hline & $(0.062$ & & $(0.073)$ & & $(0.435)$ & & $(0.033)$ & & $(0.084)$ & \\
\hline \multirow{2}{*}{ Intercept } & 30.740 & $* * *$ & 32.091 & $* * *$ & 210.329 & $* * *$ & 28.583 & $* * *$ & 31.599 & $* * *$ \\
\hline & $(5.736$ & & $(6.663)$ & & $(50.648)$ & & $(2.014)$ & & (5.772) & \\
\hline R-squared & & 1422 & & 0.1406 & & 0.0369 & & & & 0.1113 \\
\hline R-adjusted & & 1211 & & & & & & & & \\
\hline $\begin{array}{l}\text { N. } \\
\text { Observations }\end{array}$ & & 459 & & 459 & & 459 & & 459 & & 459 \\
\hline
\end{tabular}

Table 4. Regression Estimates-Dependent Variable ROA. Standard errors are given in parentheses. $* * *$ Significant at the $1 \%$ level, ** Significant at the $5 \%$ level, *Significant at the $10 \%$ level 


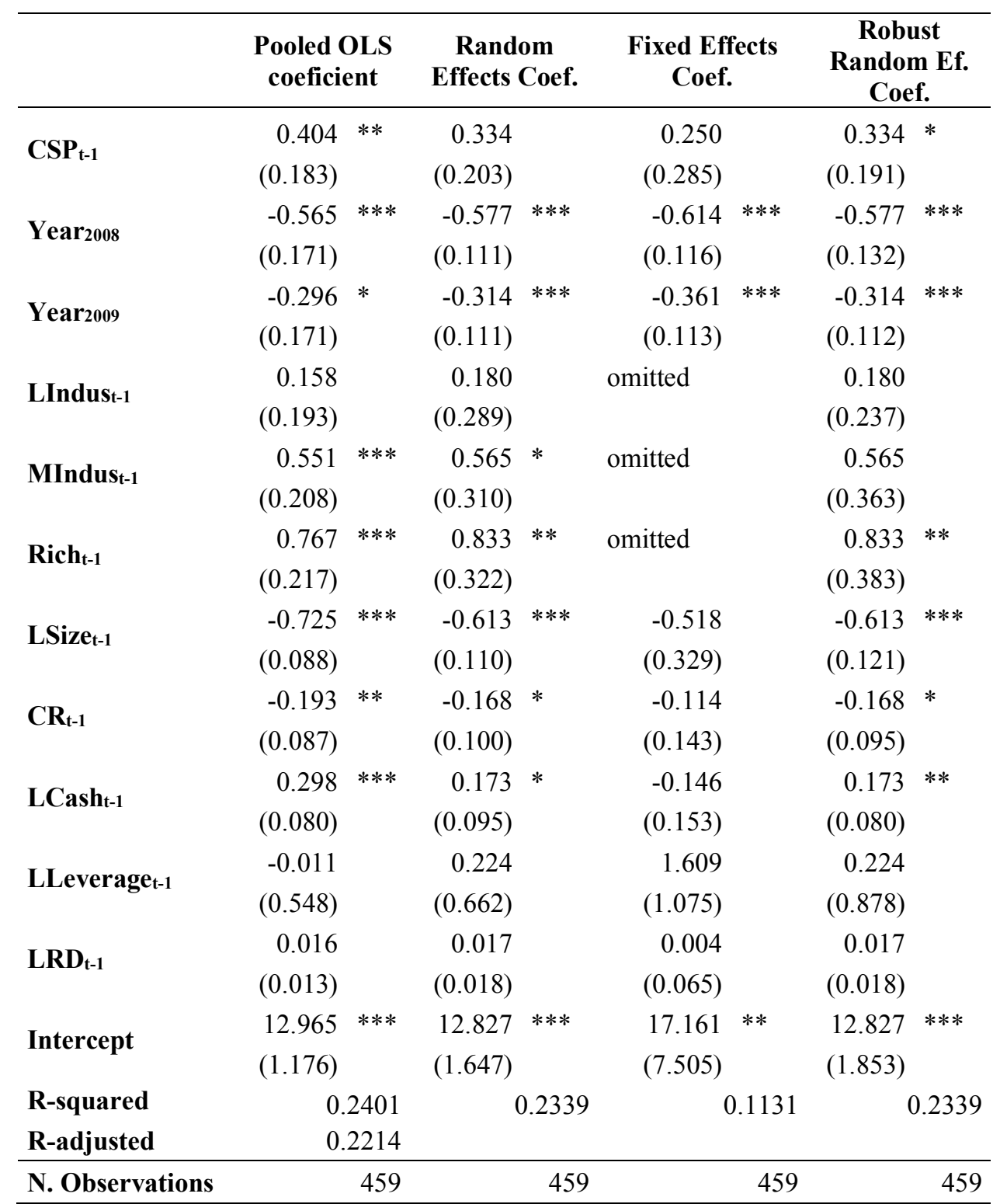

Table 5. Regression Estimates-Dependent Variable Tobin's Q. Standard errors are given in parentheses. $* * *$ Significant at the $1 \%$ level, $* *$ Significant at the $5 \%$ level, *Significant at the $10 \%$ level 